\title{
DRASKÓCZY ESZTER
}

\section{"Nem vagyok sem Aeneas, sem Pál" - Dante túlvilágjárása és elődei I. Dante és Aeneas}

\begin{abstract}
During his voyage through Hell and Purgatory led by Virgil, Dante the Pilgrim's initial fear and pusillanimity ("I am not Aeneas") turns into a strong but unspoken claim (I am a new Aeneas), and this transformation is marked by a number of references and rephrases of the Aeneid. The core of the renewal is the Christian message that follows the interpretation of allegorical commentaries. However, Dante draws on several other traditions in his artistic competition with his predecessors. Thus, he invokes Aeneas' experiences, including his deeds, his map of the Underworld, his encounters, his major virtues, his determination, and his role model, Orpheus. The symbolic journey of the Commedia is longer than Virgil's path as it eventually creates the Pilgrim's identity, based on Biblical and apocalyptical tradition as well as medieval visionary literature. ${ }^{1}$
\end{abstract}

Jelen írás egy hosszabb tanulmány első fele, amely Dante két explicit modelljéhez való viszonyulását egészében vizsgálja. E fejezet az Aeneisolvasó Dantét mutatja be elsősorban Aeneas modellszerepét járva körül a Színjátékban, érintve a dantei világ Vergiliustól örökölt helyszíneit, alakjait, erényeit és alvilági büntetetéseit. Nem kísérelem meg összefoglalni a Dante és Vergilius témájában írt könyvtárnyi munkát, csupán kiemelek néhány szempontot és jellegzetességet, amelyek segítségével a vergiliusi minta szerepét vizsgálom. Pár részletében új interpretációm nem száll vitába az évszázados értelmezési hagyományokkal, de gondo-

\footnotetext{
${ }^{1}$ A tanulmány a Nemzeti Kutatási, Fejlesztési és Innovációs Hivatal - NKFIH 121397 számú kutatási projekt keretében készült. Szívből köszönöm Vígh Évának és Mátyus Norbertnek a sok tanácsot, amellyel a cikk kéziratát javították.
} 
latmenetem során - mely teljessé a „Dante és Szent Pál” témájú második résszel válik - néhány megkerülhetetlen kérdést igyekszem tisztázni.

Hogy a szöveghelyek sokrétüségét és tudatos játékosságát jobban megértsük, összevetésem során a dantisztika bevett különbségtételét (,szerző Dante” - „utazó Dante”) alkalmazva állítom Vergiliust, az antik szerzőt a narrátor Dante mellé, Vergiliust, a Szinjáték szereplőjét Dante, az utazó mellé, valamint Aeneast, az Aeneis szereplöjét Dante, az utazó mellé.

\section{Méretkezés a nagy elődökhöz}

1.1. Az utazó Dante találkozása Vergiliusszal. Az Elysium árnyéka a Limbusban

Az első emberalak, akivel az utazó Dante a Színjátékban, első, sikertelen útja ${ }^{2}$ során találkozik, nem más, mint Vergilius, mestere és szerzöpéldaképe $\mathrm{e}^{3}$. Az antik költő fö müvét, az Aeneist kitartó szorgalommal és nagy szeretettel tanulmányozta, és tőle vette át a szép ('emelkedett', 'tragikus') stílust, mely dicsőséget szerzett neki. Dante, mikor legkedvesebb szerzője árnyát megpillantja, a miserere („könyörülj [rajtam]”) szóval fordul hozzá segítségért egyszerre idézve Dávid király bünbánati zsoltárának ${ }^{4}$ első szavát, valamint Aeneas kérését Sibyllához, hogy legyen vezetője az Avernusban, és tegye lehetővé találkozását halott apjával, Anchisesszel $^{5}$.

2 A szereplő Dante első, sikertelen útja alatt a sötét erdőtől kezdve a földi paradicsom napsütötte dombhátáig tartó igyekvését értjük, amikor útját állja három vadállat, akik közül a telhetetlen bírvágyat jelképező nőstényfarkas végül visszafordulásra készteti (Pk. 1, 1-61). Magyarul a témáról és a három vadállat értelmezéséről ld. SALLAY (2011: 17-31); PÁL (2009: 101-102); VÍGH (2017: 87-100), MÁTYUS-NAGY (kézirat).

${ }^{3}$ Pk. 1, 8. Az ének magyar fordítását MÁTYUS-NAGYtól idézem (kézirat). A Pokolból magyarul a megjelenés alatt álló kommentárunkból (Kelemen J. (szerk.), A dantei Pokol: kommentárok), míg a Purgatóriumból és a Paradicsomból NÁDASDY Ádám fordításában idézek. Saját fordítást használok abban az esetben, ha a meglévőkkel nem értek teljesen egyet.

4 Zsolt 51, 3. A Bibliát mindig a Káldi-féle Neovulgáta-fordítás szerint idézem: Ó- és Újszövetségi Szentírás a Neovulgáta alapján, Budapest, 2001.

5 „Gnatique patrisque, / alma, precor, miserere” („Könyörgök, / Szánd az atyát s a fiút, kedves"). Niccolò Tommaseo kommentárja és Giovanni Pascoli értelmezése nyomán 
Vergilius, ahogy az a Pokol második énekéből kiderül, pontosan a bűnös életet jelképező sötét erdóbe ${ }^{6}$ éppen visszatérni készülő Dante megsegítésére érkezett a Limbusból, ahol az antik, pogány költőnagyságok - Homéros, Horatius, Ovidius, Lucanus $-^{7}$ társa. A pokol első körében, tornácán, a keresztség nélkül meghaltak sóhajai rezgetik a sötét és ködös levegőt ${ }^{8}$, míg az ókor nagyjai a vergiliusi elysiumi mezőket ${ }^{9}$ idéző $^{\prime}$ helyszínen lakoznak ugyanitt. Egy nemes kastélyon áthaladva magas, nyílt és világos helyre érkeznek az utazók, ahol zöld pázsit felett ${ }^{10}$ gyülekeznek a nagy szellemek, köztük maga Aeneas a többi eposzi hős seregszemléjében $^{11}$, valamint a filozófusok, tudósok családja. A Szinjátékban, tehát, a legkiválóbb bölcsek, költők és szereplőik az elysiumi boldogok (hősök, költők, felfedezők, művészek) sorsának árnyékát kapják.12

Ez az „Elysium” a pokol tornácán zárványt alkot a dantei alvilágban, és egyedülálló hommage az antik kultúra nagyjainak, akik békésen társalognak, méltóságot sugárzó arccal, fényben és nyugalomban, és a legbölcsebbeket tisztelettel és rajongással hallgatják. Az isteni akarat szerint „Dicső hírük és nevük, [...] az égben kegyet nyer, s jutalmuk ez"13. Ám ez a kivételezett helyzet kimerül a kellemes környezetben, a földi értékek és nemes szokások továbbvitelében, ${ }^{14}$ és nem mentes a

hangsúlyozza: RIGO 1994: 74. Vergilius műveiből magyarul LAKATOS István fordításában idézek.

${ }^{6}$ Pk. 1, 2. N.b. Aeneasnak is ősi (Verg. A. 6, 179), sűrű erdőn (uo. 131-132) kell áthatolnia alvilági útja során.

${ }^{7}$ Dante a költők „,szép iskoláját” $(P k .4,95)$ hasonlóképpen csoportosítja az Új élet XXV. fejezetében (ford. JÉKELY Zoltán, KARDOS 1965: 45); A nép nyelvén való ékesszólásról címü művében (II vi 7) Vergilius, az Átváltozások Ovidiusa, Statius és Lucanus a megnevezett négy legkiválóbb „verselő poéta” (ford. MEZEY László, KARDOS [1965: 387]).

8 Pk. 4, 10; 26-27. Az énekből TóTH Tihamér fordításában idézek (kézirat).

${ }_{9}^{9}$ Verg. A. 6, 637-892.

${ }^{10}$ Vö. a vergiliusi Elysiumban a vidám berkeknek örökzöld, / bübájos mezejével: Verg. A. 6, 638-639.

11 Ld. BORZSÁK (1968: 3).

12 Vergiliusnál magnanimi heroes (Verg. A. 6, 648), Danténál spiriti magni (Pk. 4, 119).

${ }^{13} P k .4,76-78$. NÁDASDY Ádám fordítása.

${ }^{14}$ Ugyanezt kapják a vergiliusi boldogok is jutalmul: „Ahogyan - míg éltek - örültek / Harci szekérnek, fegyvernek, fényes lovaiknak, / Épp így holtukban sem szűnik e vágyuk irántuk. / Jobb fele mint balról, a gyepen, lakomáznak is erre, / Rágyújtván a babérbokrok jóillatu fészkén / Víg győzelmi dalokra..." (Verg. A. 6, 651-658). 
szenvedéstől: e kiválóságok is - akárcsak a többi kereszteletlen lélek remény nélkül vágyakoznak ${ }^{15}$, ami maga a „szenvedés definíciója” ${ }^{16}$.

\subsection{Dante kétségei és Vergilius válaszai az alászállás előtt}

Vergilius magyarázza el a segítségért esengő Utazónak, hogy a napsütötte földi paradicsomig nem a látható és addig megkísérelt ösvényt, hanem egy másik utat kell bejárnia, áthaladva a poklon és purgatóriumon, és e hosszú út során, amely teljes túlvilági zarándoklatának csaknem kétharmada, ő lesz a vezetője. Dante, meghallván, milyen nehéz feladat áll előtte, a következő kétségeit tárja a bölcs költő elé: (1) elég-e az ereje, elég erényes-e egy ilyen roppant úthoz? ${ }^{17}$; (2) mi ennek az utazásnak az oka s célja, és (3) ki ad rá engedélyt? ${ }^{18}$

A kérdések felvetésével párhuzamosan az Utazó megnevezi túlvilágjárásának két legfontosabb mintáját: Aeneast (Silviusnak apja ${ }^{19}$ ) és Szent Pált (Választott Edény). Költő-vezetőjéhez fordulva - Te mondod tizenöt sorban idézi fel Aeneas descensusának három fő jellegzetességét: testben, még romlandó állapotban ment a halhatatlan világba, és ott érzékeinek birtokában volt; tette ezt isteni engedéllyel; valamint, hogy küldetésének telosa pontosan tudható:

ugyanis őt az áldott Róma és a birodalom atyjául

az egek legmagasabbikában választották ki:

ez is [a város] és az is [a birodalom], ha az igazat akarjuk mondani,

15 Pk. 4, 42.

${ }^{16}$ Mátyus Norbert megjegyzése.

${ }^{17}$ Az eredeti virtù (Pk. 2, 11) 'erény', 'erő', 'képesség', ' felkészültség', nehezen fejezhető ki egy szóval. BABITS és NÁDASDY erőnek (,vizsgáld erőmet, vajjon tehetős-e” B. M.; „tekintsd erőmet: elég-e vajon” N. Á. ford.), HOFFMANN-MÁTYUS erénynek fordítja („,nézd erényemet, hathatós-e”). A túlvilágjárások során az utazó lelki-morális állapota a leglényegesebb, vagyis az erény, hiszen a legtöbbször csak a lélek teszi meg az utat (pl. Tundalus látomása). Azonban - ahogy szerzőnk hangsúlyozza - Aeneas testben lép át a halottak birodalmába, és a nyomán Dante is hús-vér alakként halad át a pokol és purgatórium körein árnyékot vetve, olykor elfáradva, és a purgatóriumi éjjeleken megpihenve. Így számukra egyfajta fizikai erőnlét is szükséges az úthoz, még ha ez az erő valójában az erény kifejeződése.

18 Pk. 2, 10-31.

${ }_{19}$ Pk. 2, 13, vö. Verg. A. 6, 763-766. 
a szent hely számára alapíttatott,

ahol a nagy Péternek követője székel. (Pk. 2, 20-24)

A másik modell, Szent Pál paradicsomi útját mindössze egy tercina jeleníti meg itt, az apostol elragadtatásának célját és következményét hangsúlyozva:

Aztán ott járt a Választott Edény,

bizonyságot hozott annak a hitnek,

mely utat nyit az üdvösség felé. (Pk. 2, 28-30)

A túlvilágjárás opusa ${ }^{20}$ előtt álló Dante hozzájuk méri magát, és első kijelentése, kételye szerint „nem Aeneas, és nem Pál”, és senki - sem saját maga, sem más - nem tartja méltónak erre, így attól tart, hogy örült ${ }^{21}$ vállalkozás elindulnia, pontosan amilyen Odysseus utolsó útja volt ${ }^{22}$.

Dante három kérdése közül Vergilius teljes mértékben csupán a harmadikat válaszolja meg, és részben a másodikat. A mester, hogy kishitűségétől és félelmétől megszabadítsa pártfogoltját, elmondja, ki és miért küldte őt a megsegítésére. Szűz Mária szánta meg Dantét, mikor a sötét erdőnél bolyongott, enyhítve a szigorú, isteni ítéleten (amely a főhős bűnéért, az igaz útról letérésért járna), Szent Lúcia gondjára bízta, akinek a firenzei költő nagy tisztelője volt. Lúcia pedig Beatricéhez, Dante szerelméhez fordult, hogy támogassa barátját, aki őt annyira imádja, hogy érte - az Új élet megírásával - kiemelkedett „a népnyelvü seregből”23. A Mennyei Rózsából szállt alá Beatrice a Limbusba, és itt kérte

${ }^{20}$ Aeneast vezetője, Sibylla ugyan azzal biztatja, hogy az alászállás könnyü, csupán a visszajutás fáradságos munka („[...] facilis descensus Averno: / [...] / sed revocare gradium superasque evadere ad auras, / hoc opus, hic labor est. [...]" Verg. A. 6, 126129), ennek azonban nemsokára ellentmond majd, amikor az áldozatok bemutatása után Aeneas, kivont kardját szorongatva, belépni készül a Hádésba: „Most van szükség hős lélekre s a szívben erélyre!” („nunc animis opus, Aenea, nunc pectore firmo” uo.

261.)

${ }^{21}$ folle, Pk. 2, 35.

${ }_{22} P k .26,125$ és $P d .27,83$.

${ }^{23}$ Pk. 2, 105. 
meg Vergiliust, hogy ékes beszédével „és mindazzal, ami szükséges lehet [Dante] megmeneküléséhez, segítse" 24 .

Vagyis, Dante útja küldetés, mely isteni akaratból és égi segítséggel valósul meg, tehát e tekintetben méltó két nagy elődjéhez, akiknek túlvilágjárásai „egymás komplementerei” ${ }^{25}$. Az Aeneis, ahogy a latin Biblia, Dante legfőbb forrásai lesznek, és „folyamatos viszonyítási pontként szolgálnak a továbbiakban”, és „melléjük társul immár harmadik szent könyvként" a Szinjáték ${ }^{26}$.

A Vergiliushoz intézett, első kérdésre - hogy elég-e Dante ereje, elég erényes-e egy ilyen roppant úthoz - csak az utazás maga adhat választ. A második kérdés másik felére, amely a túlvilágjárás céljára vonatkozik, a szerzőtől a Szinjáték más pontjain, valamint a Cangrande della Scalához írt, XIII. levélben kapunk feleletet, teljességében pedig a látomásirodalmi hagyomány ismeretében érthetjük meg. A XIII. levél tanúsága szerint a Szinjáték didaktikus célkitűzése, hogy a földi halandókat „a boldogság állapotára vezesse”27, tehát Dante egyéni javán túl az egész, bünben élő emberiség hasznára is történik ez a zarándoklat. Ugyanakkor „a lelkek túlvilági állapotát” bemutatva a szerző a korabeli társadalmat is le akarja képezni és bírálni: ez a törekvés már az első apokaliptikus-vizionárius szövegekben (így a Péter-apokalipszisben ${ }^{28}$ és Szent Pál látomásában ${ }^{29}$ ) is jelen van.

Az érdekeltek széles köréhez ez az erkölcstankönyv természetesen csak akkor jut el, ha az utazást és az ott látottakat Dante megírja. A denuntiatio kötelessége a látomásirodalmi hagyomány toposza ${ }^{30}$ János jelenéseitől kezdve („Amit látsz, írd le egy könyvbe!” Jel 1,11). A Színjáték utazóját legfontosabb feladatára először Beatrice figyelmezteti a földi paradicsomban: „... a világ hasznára, mely rosszul él / tartsd most sze-

\footnotetext{
24 Pk. 2, 67-69.

25 PICONE (2017: 313).

${ }^{26}$ HOFFMANN-MÁTYUS.

27 XIII. Lev. Mezey László fordítása. KARDOS (1965: 511).

${ }^{28}$ Magyarul: PESTHY M., Péter-apokalipszis.

${ }^{29}$ Magyarul: ADAMIK T. ford., Szent Pál apostol látomása.

${ }^{30}$ Erről ld. BAROLINI (2015: 462 skk).
} 
med a szekéren, és amit látsz, / azt írd majd meg, ha oda visszatérsz!" 31 Másodszor pedig Szent Péter szólítja fel ugyanerre:

És te, fiam - hiszen tested halandó, s még visszamész oda -, nyisd ki a szádat:

ne titkold, amit én sem titkolok!"32

\section{Dante Vergiliusa}

A középkor a Negyedik ecloga próféciáját Krisztusra vonatkoztatva Vergiliust mint a kereszténység előtti keresztényt és látnokot tisztelte. A számos Vergilius-legenda közül az egyik szerint maga Szent Pál is meglátogatta a költő sírját, és e szavakkal siratta meg őt:

Quem te, inquit, reddidissem,

si te vivum invenissem,

poetarum maxime! 33

Dante Vergiliusa, ezekkel a korban elterjedt legendákkal szemben, pogány, tehát művével, a Negyedik eclogával az alkotója számára rejtett üzenetet közvetített. Hiába jelenik meg Statius a Szinjátékban mint titkos keresztény, aki pontosan Vergilius Negyedik eclogájának hatására keresztelkedett meg $^{34}$, a szeretett mester sorsát Alighieri túlvilágában ez a post mortem térítés nem befolyásolja. A latin költőt Macrobius megállapításától ${ }^{35}$ kezdve az antik tudomány és müvészet legfőbb letéteményesének tartják, költészeti tekintélynek és stílusmodellnek, akinek etikai, politi-

\footnotetext{
${ }^{31} \mathrm{Pg}$. 32, 103-105 (saját ford.).

$32 \mathrm{Pd}$. 27, 64-66. NÁDASDY Á. ford.

33 ZIOLKOWSKI-PUTNAM (2008: 413).

34 Te küldtél legelőször / a Parnasszus forrásaiból inni / s a te fényed vitt Istenhez először. / Úgy voltál, mint aki maga mögé / tartja a lámpát: neki nem világít, / de segíti az utána jövőket, / hiszen ezt mondtad: „Új kor születik, / igazság lesz majd, mint az ősidőkben,/ s új ivadék száll le hozzánk az égből." / Miattad lettem költő, majd keresztény... (Pg. 22, 64-73 Nádasdy Á. ford., kiemelés tőlem: D. E.)

${ }_{35}$ Macrobius szerint Vergilius minden tudomány kiváló ismerője (Somn. Scip. I 6, 44). ld: BELLOMO (2013: LI).
} 
kai és vallásos nézeteit az értelem és humanitas tökéletes harmóniában hatja át. ${ }^{36}$

Dante számára - bár ismeri és idézi a Georgicát és az Eclogákat is Vergilius az Aeneis szerzőjeként jelentős. A mü cselekményének lényeges elemeit történelmi ténynek tekinti (vagyis, hogy Aeneas valós személy volt, eljött Trójából és megalapította Rómát), a katabasist pedig irodalmi ténynek. ${ }^{37}$ Maga Vergilius bizonytalanítja el olvasóját a leírtak igazságtartalmát illetően azzal, hogy főhőse az álom elefántcsontkapuján hagyja el az alvilágot ${ }^{38}$. Az Aeneis allegorikus értelmezései - Aelius Donatus, Tiberius Claudius Donatus, Servius, Macrobius, Fulgentius, de főként Bernardus Silvestris kommentárjai nyomán - a középkori olvasók számára meghatározták a mü befogadását. ${ }^{39}$ Dante a Vendégségben (IV xxvi) Fulgentiust követve az Aeneist mint az életkorok egymásutánját és az egyes korokhoz köthető erények útmutatóját interpretálja. A dantei allegóriában a ló a természetes vágyat jelenti (2703), a lovas az észt (2708), a zabla a Mérsékletet (2715), a sarkantyú pedig az

Állhatatosság vagy Erőslelkűség, s olyan erény, amely megmutatja, hogy hol kell megállni és harcolni. Vergilius, a mi legnagyobb költőnk, ilyen megzabolázottnak mutatja Aeneast, az Aeneis azon részében, ahol ezt az életkort ábrázolja; tehát a negyedik, ötödik és hatodik énekben. És micsoda önmérséklet volt az, amikor Didótól ráhalmozott oly sok gyönyörüség élvezése után [...], bár oly sok örömét lelte a vele való együttlétben, útnak indult, hogy a becsületes, dicséretre méltó, hasznot hajtó utat kövesse [...]. Micsoda sarkallás volt az, amikor ugyancsak Aeneas Sibyllával kettesben vállalta az Alvilágba való lemenetelt, atyja, Anchises lelkének megkeresésére, annyi veszéllyel szemben...40

\footnotetext{
${ }^{36}$ CONSOLI-RONCONI (1976: 1037).

${ }^{37}$ Köszönöm Mátyus Norbert magyarázatát erről a sokat vitatott kérdésről.

38 Verg. A. 6, 893-898. A témáról ld.: VINCZE (2005: 89-116).

39 COMPARETti (1872, vol. 1); PAdOAN (1977: 207-222); ItAlia (2008: 329-417); ITALiA (2012).
}

${ }^{40}$ Vend. IV xxvi, 2719-34. SZABÓ Mihály fordítása. KARDOS 1965: (334-335). 
Dante észlelte az Aeneis zavarba ejtő problémáját, amely már a történetet újraíró Ovidius számára is egyértelmú volt ${ }^{41}$ : a Dido-epizód nem illik a „harcokat s hőst" éneklő eposzba, ${ }^{42}$ sem pedig a pius Aeneas tettei közé. Dante megoldási kísérletként $A z$ egyeduralom címü traktátusában Didót Aeneas feleségének tekinti, és úgy véli, ez a házasság (éppúgy, ahogy korábban a Creusával, később a Laviniával kötöttek is) nemesebbé tette Aeneast:

[Aeneas] Második asszonya Dido volt, a karthágóiak királynője és anyja Afrikában. S hogy valóban felesége volt, [...] költőnk bizonyítja a negyedik énekben, így beszél ugyanis Didóról:

Nem titkos szerelem többé Dídó szíve vágya, „Házasság”-nak hívja a bünt, így rejti magában.

(Egyed. II iii 188-192) $)^{43}$

Vergilius sorait szerzőnk minden bizonnyal szándékosan értelmezi félre, hogy Aeneast - akit több szempontból is modelljének tekint - erkölcsileg feddhetetlennek mutathassa be.

A Vendégség allegorikus és morális-vallásos Aeneisinterpretációjához $A z$ egyeduralom írásakor új, politikai aspektus társul: Dante felfedezi az isteni elrendelés fontosságát, amely a Római Birodalom megteremtését akarta és vezérelte. Ez az értelmezési séma nemcsak

\footnotetext{
${ }^{41}$ Ld. CASALI (1995: 66-76).

42 Dido Aeneaséhoz hasonló sorsot élt meg: zsarnok és gyilkos bátyja miatt menekülni kényszerült híveivel együtt, ám leleményességével hazát szerzett népének, és most (gyönyörű) királynőként virágzó várost kormányoz és épít (ld. Venus bemutatását: Verg. A. 1, 340-368). Aeneast, a másik üldözöttet, szíves vendégszeretettel fogadja be, addigi történetének pedig hallgatója lesz, a 2-3. ének címzettje. Azonban, amikor a kegyes és igazságos hős rendeltetését és célját követve indulni készül, kétszer is úgy dönt, hogy az őt szerető előtt titkon hagyja el a várost. CASALI (1995: 67) amellett érvel, hogy Ovidius kritikája a Keservekben -“Ám fegyver s a vitéz költője is íme, bedugta / Dido ágyába fegyverestől a vitézt / és az egészből ezt olvassák legszivesebben / ezt a szerelmet, amit nem füz össze frigy" Tristia 2, 533-536, Erdődy János ford.) részben a müfajok vegyítésének szól, részben pedig Aeneas morális következetlenségéről, amelyre felhívja a figyelmet az "ágyába fegyverestől" utalás: Dido ágyának közelébe Vergilius szövegében ugyanis csak egyszer, az öngyilkosságakor kerül a vitéz fegyvere (Verg. A. 4, 495: arma viri, thalamo...).

${ }^{43}$ Az egyeduralomból Sallay Géza fordításában idézek. KARDOS (1965: 428).
} 
politikaelméleti írásának fő tétele lett (vö. Egyed. II i 2-3), hanem az Aeneis újraolvasásának is a kiindulópontja ${ }^{44}$, hiszen Aeneas a római nép (populus ille sanctus pius et gloriosus, Mon. II v 5) öse, amelynek „szent magjából" Dante is származtatja magát $(P k .15,76)$. Aeneas utódainak pedig maga Iuppiter ígérte, hogy egy „imperium sine fine” ${ }^{45}$ uralkodói lesznek, ami Ágoston értelmezésében nem egy „hamis és hazug isten” 46 ígérete, hanem az egyetlen igaz istené. ${ }^{47}$

Az Aeneis nemzeti-birodalmi eposz, amely „az Aeneas-mondák feldolgozása során múlt, jelen és jövő hatalmas képeiben a római történelem és Augustus politikai törekvései között teremt összefüggést" ${ }^{\prime 4}$. Dante világlátását alapvetően formálja Vergilius politikai állásfoglalása: innen származik - minden valószínüség szerint Servius kommentárján is keresztül, aki először javasolja, hogy az Aeneist mint gesta populi Romanit olvassák ${ }^{49}-A z$ egyeduralom egyik fö tézise, mely szerint csak a római császárkor első szakaszában, a pax Romana idején élhetett boldogságban az ember a földön. Ekkor kormányzott jó császár, és béke uralkodott az egész világon, s ez volt „,a halandóknak az az állapota, amelyet az Isten Fia várt, vagy midőn akarta, maga rendelte el, amikor az emberek üdvösségére emberi alakot készült magára ölteni" ${ }^{50}$. Krisztus tehát azzal, hogy a Római Birodalom területén és idejében született, szentesítette az Aeneas által alapított államot, és a legkiválóbbnak választotta ki azt az emberiség történelmében.

Amíg Vergilius vezeti Dantét a Szinjátékban, addig az Aeneis a mü egyik legfontosabb hipotextusa, ám az utalások az antik eposzra nem egyenletesen oszlanak el. Hollander ${ }^{51}$ a legtöbb idézetet és újraírást a Pokolban mutatja ki (193 biztos és 80 valószínű utalás), a latin költemény

\footnotetext{
${ }^{44}$ PADOAN (1970: 677-679).

45 Verg. A. 1, 278-279.

46 Vö. Pk. 1, 72.

${ }^{47}$ Aug. Serm. CV 7 (PL, 38, col. 623). Ágoston Vergilius-értelmezéséről ld. még Petrarca IV. Liber sine nomine-levelét: ERTL P. ford. (2018: 92-93.)

48 TRENCSÉNYI-WALDAPFEL (1974: 281).

${ }^{49}$ Ad Aen. 6, 752: „opus hoc apellatum esse non Aeneidem, sed gesta populi Romani” Idézi: ITALIA (2008: 334).

50 Mon. I xvi 1; MÁTYUS-NAGY.

${ }^{51}$ HOLLANDER (1993: 248-251).
} 
jelenléte halványodik a Purgatóriumban (103 biztos és 28 valószínü felidézés), és a kezdő canticához képest nagyjából harmadára csökken a Paradicsomban (68 biztos és 15 valószínü allúzió). A Színjáték főként az indításában vergiliusi: a költemény első 707 sorának 70 Vergiliusáthallásával szemben még a Biblia is alulmarad mint idézett forrás. ${ }^{52} \mathrm{Az}$ első öt ének tehát a leghosszabb Aeneis-újraírás a Szinjáték szövetében, de korántsem az egyetlen: így fogja Pier della Vigna epizódja (Pk. 13, 20-108) bizonyítani a mester Polydorus történetének (Verg., A., 3, 22-49) igazságát; és Dante éppúgy kapja meg tulajdon sorsának jóslatát ősétől, Cacciaguidától (Par. 15-17) a túlvilágon, ahogy Aeneas Anchisestől (Verg., A. 6., 678-702), igazolva a Paradicsomban is a latin eposz egyedülálló modell-szerepét.

Az első hét énekben, amely talán a mü első elkészült és közreadott egysége volt, ${ }^{53}$ az utazó Dante és Vergilius kapcsolata formális - a toszkán költő leggyakrabban érzelmi töltet nélkül nevezi meg vezetőjeként, uraként, mestereként (Pk. 2, 140) Vergiliust. ${ }^{54}$ Ezekben az énekekben Dante az Aeneist az imitatio eszközével idézi fel, egyértelmü párhuzamot vonva Aeneas leszállása és tulajdon utazása között. A sötét erdőből szabaduló Dante mint egy hajótörött néz vissza az elhagyott veszélyekre: „És mint aki szapora lélegzettel, / miután kijutott a tengerből a partra, / visszafordul a veszedelmes víz felé, és rámered, / így fordult vissza még menekülésben lévő lelkem, / hogy újra megszemlélje az utat, / amely még senkit nem hagyott élve." (Pk. 1, 22-27). A metafora kontextusidegen és pusztán retorikus választásnak tünik addig, amíg nem vonunk párhuzamot Aeneas helyzetével a latin eposz kezdetén: a Iuno haragja a múltbeli sértésért (Paris ítélete, Ganymedes) és a jövőbeli (Karthágó) kudarcért - keltette rettenetes tengeri viharból ${ }^{55}$ megmenekülve, a kart-

\footnotetext{
52 HOLLANDER (1993: 248).

53 Az első hét éneket Giovanni Boccaccio (1373-1375) és Benvenuto da Imola (13751380) kommentárja szerint Dante még a száműzetés előtt írta (idézi: BAROLINI [1993: 164]). Boccaccio és Benvenuto da Imola állítását a Szinjáték ma elfogadott (ld. PADOAN [1993]) datálása nem támasztja alá: eszerint Dante már a száműzetésben, Lunigianában, 1306-ban kezdte írni a Pokolt, és 1308-ban adta közre az első hét éneket.

54 BAROLINI (1993: 163).

55 Verg. A. 1, 80-129.
} 
hágói partra sodort Aeneas néz így vissza a tengerre, miközben társai „a homokban / sós létől csepegő, senyvedt testtel leomolnak"56:

Aeneás ezalatt felhág egy oromra, hogy onnét

Lásson a tág tengerre, ha tán ide tért a viharvert

Antheus vagy Capys is, vagy a phryg kétrend-evezősök,

Vagy paizsok boritotta magas tatján ha Caícus. (Verg. A. 1, 181-184).

Dante és vezetője kapcsolata az út során elmélyül, a legszorosabb emberi viszonyok skáláját futja be: a meghitt tanítvány-mester kapcsolatból fiúi szeretet (pietas) válik, a mesterből „édes apa"57, „legédesebb apa”58, „,édes, drága apa"59, „,igaz apa”60, „,több mint apa”61 lesz. Sőt, egy érzelmi tetőponton Vergilius mint anya kapja fel Dantét, és viszi „mellén [...] szorítva / mint kisfiát, és nem mint útitársát" ${ }^{62}$ :

A vezetőm tüstént megragadott, mint anya, aki furcsa zajra ébred, látja maga körül: lángol a ház, fölkapja gyermekét s úgy menekül, csak ővele törődve, nem magával, úgy fut, ahogy van, még inget se vesz. (Pk. 23, 37-42).

Mikor az Utazó ráébred, hogy mestere eltünt, és nem kíséri tovább túlvilági útján, ugyanazzal a retorikai megoldással - a név háromszoros ismétlésével siratja („De Vergilius eltünt a körünkből, / Vergilius, atyám, Vergilius! / Akire bíztam lelkem tisztulását!"63 Pg. 30, 49-51) - ahogy Orpheus levágott feje szólongatta Eurydicét a Georgicában ${ }^{64}$, ezzel fel-

\footnotetext{
56 Uo., 172-173.

${ }^{57}$ Pk. 8, 110; Pg. 4, 44; 15, 25 és 24; 17, 82.

58 Pg. 30, 50.

${ }_{59} \mathrm{Pg} .18,13$.

${ }^{60} \mathrm{Pg} .5,7$.

${ }^{61} \mathrm{Pg} .22,4$.

62 Pk. 23, 50-51. CONSOLI-RONCONI (1976: 1040).

63 NÁDASDY Á. fordítása.

${ }^{64}$ Verg. G. 4, 523-7 „Ám a jeges nyelv Eurydicét onnét is imádta, / Eurydicét hivogatta, midőn libegett el a lelke, / Eurydicé neve visszhangzott a folyókon, a parton."
} 
idézve a másik nagy katabasis-történetet szeretett szerzője tollából, és a (szerelmi) veszteség tragikumával zárva le közös útjukat.

Vergilius - a Szentírás „szerzője” mellett - az egyetlen, akinek Dante fenntartja az autore megnevezést: a tudás ${ }^{65}$ és tekintély, amelyet a Szinjáték tulajdonít neki, lehetővé tette, hogy évszázadokon keresztül az Értelem allegóriájaként értelmezzék alakját a kommentárok. Azonban autoritását a mű számos pontján meg is kérdőjelezi, lebontja, majd újra felépíti: ${ }^{66}$ mint vezető nem tévedhetetlen - szemben az angyal által vezetett túlvilági utazásokkal -, és nem tudja minden esetben Dantét megvédeni a pokol lakóitól. Égi segítségre szorulnak a fúriákkal és Medusával szemben, ${ }^{67}$ Vergilius "térképe" még Krisztus alászállása előttről való, így az utazók egy ördögtől tudják meg, hogy a Rondabugyrok egyik hídja akkor beszakadt ${ }^{68}$; és a démonok rá is szedik a bölcs mestert ${ }^{69}$.

A purgatórium-hegy utolsó nagy próbatételénél, a földi paradicsomot körülvevő tüzfalnál, amelybe az Utazónak be kell lépnie, Vergilius első rábeszélési kísérletei elégtelennek bizonyulnak: sem a józan érvelés, sem az érzelmi ráhatás, sem a közösen átélt nehézségek felidézése nem ér el hatást. ${ }^{70}$ Csak a szeretett hölgy nevének hallatán kel életre Dante félelemtől dermedt szíve, és nyer bátorságot a próbatételhez. Idáig tart Vergilius autoritása, szónoki hatékonysága, vezetői szerepe, és innen mozgatja tovább Beatrice közelsége: a megváltó szerelem ereje erősebbé válik a Vergilius jelképezte értelemnél. Miután átjutottak a lángfüggönyön, és megtették az Édenhez vezető utolsó lépcsőket, Vergilius elbúcsúzik fiától-tanítványától, és önmaga urává koronázza Dantét:

«...az időleges és örök tüzet is

láttad, fiam, és eljutottál oda,

ahonnan tovább én már nem látok.

\footnotetext{
${ }^{65}$ Nevezi Dante nemcsak bölcsnek, amely állandó jelzője, hanem nemes bölcsnek, ki mindent tudott $(P k .7,3)$ és minden tudás tengerének $(P k .8,7)$ is.

66 JACOFF-SCHNAPP 1991: 2-3.

${ }^{67}$ Pk. 9, 43 skk.

68 „,Tegnap volt épp - öt órával odébb - / ezerkétszázhatvanhat éve annak, / hogy itt az áthidalás leszakadt." Pk. 21, 112-114, NÁDASDY Á. ford.

${ }^{69}$ Pk. 21-23. Ezekről az epizódokról ld. BAROLINI (1993: 144 skk).

${ }^{70}$ Pg. 27, 20-32.
} 
Idáig vezettelek ésszel és ügyességgel, most már vezessen tovább a vágyad; túljutottál meredélyeken, túljutottál szorosokon. [...]

Ne várj többé sem szavamra, sem intésemre;

akaratod szabad, ép és hajlik a jóra,

hiba lenne nem követned:

a magad urává koronázlak!»71

Vergilius a teljes út során tisztában van korlátaival - mint pogány az antik-keresztény hibrid alvilágban -, és azzal is, hogy hol helyezkedik a dantei világban az a határ, amelyet már nem is léphet át. Ám, ahová a szereplő Vergilius nem jut el, azokat a világrészeket is meghatározza az Aeneis útleírásának néhány aspektusa.

\section{Alvilágjárás a Színjátékban Vergilius nyomán}

Az Aeneis nagyon sokrétűen formálta a Szinjáték szövegét: mint túlvilági utazást nyelvileg-stilisztikailag magas szinten elbeszélő eposz a dantei költemény legfontosabb poétikai-narrációs mintája. Tárháza alakoknak és az alvilágban betölthető funkcióknak, így a bíróknak: a vergiliusi Minos és Rhadamanthys szerepeinek összeolvasztásával készül el a dantei Minos, aki elé a pokol II. körében járulnak a lelkek, hogy büneik súlyosságának megfelelően kapjanak helyet ${ }^{72}$. Vergiliusi mintát követnek az Inferno révészei: a dantei Charon, az „ősz hajú, borzas öreg”, akinek „a szemei körül tűzkarikák” vibrálnak, egyenesen az Aeneisből érkezett („Szörnyü Charón, ez a borzalmas révész, kinek állát / Borzas, szürke szakáll rútítja, tekintete lángol" $)^{73}$, de ördög74, míg Phlegyas csak a nevét kapja a latin eposzból. ${ }^{75} \mathrm{~A}$ két alvilág őralakjai között is tagadhatatlan a hasonlóság: a dantei Cerberus éppúgy „három torokból kutyaként ugat"76, mint a vergiliusi' ${ }^{77}$. A büntető szörnyek egy részét is az Aeneisből

${ }^{71}$ Pg. 27, 127-132, 139-142. Saját fordítás, kiemelés tőlem - D. E.

72 Pk. 5, 5 skk vö. Verg. A. 6, 433: Minos „crimina discit”; Rhadamanthys a Tartarusban (Verg. A. 6, 567): „castigatque auditque dolos subigitque fateri” (RONCONI 1976: 1045).

${ }^{73}$ Pk. 3, 83, 99 То́тн Tihamér ford., vö. Verg. A. 6, 300 sk.

${ }^{74}$ Pk. 3, 109.

${ }^{75}$ Pk. 8, 13 skk. vö. Verg. A. 6, 618. A dantei Charon és Phlegyas forrásairól és korai ábrázolásairól ld.: FORTE (kézirat).

76 Pk. 6, 14. 
kölcsönzi Dante, felvonultatja a hárpiákat - akik nemcsak a Hádésben, de a Stróphadokon is ijesztik Aeneast ${ }^{78}$-, a kentaurokat; a vergiliusi Geryont viszont alaposan átformálva teszi a Pokol egyik legrémisztőbb őralakjává.

De tárháza az Aeneis helyzeteknek is, "olyan mikro-invencióknak, amelyek a Színjáték építőelemei lesznek"79. Az utazó Dante kedves barátját, Casellát találja a Purgatórium szigetén gyülekező árnyak között, akit szeretne megölelni, ám:

Jaj, üres árnyak, látszólag szilárdak!...

A karom háromszor zártam köré,

s mindháromszor csak magamat öleltem! ${ }^{80}$

Ugyanígy háromszor próbálta ölelni Anchisest Aeneas, mikor oly sok veszély és bolyongás után végre viszontlátja apját az elysiumi pázsiton:

Háromszor próbálta nyakát átfonni, hiába,

Háromszor surrant ki a testtelen árny, eloszolván,

Mint lehelet-lágy szél, mint felszakadó rövid álom.

(Verg. A. 6, 700-702)

Dante számára az Aeneis VI. éneke a legfontosabb térkép és „útikönyv"81, amelyet felhasznál a pokol és purgatórium birodalmainak megalkotásához. A pokoli vízrajz lényegében Vergiliustól származik ${ }^{82}$ : a Hádés határát jelző Acherónt a dantei pokol határán találjuk ${ }^{83}$; a mocsaras Sty ${ }^{84}$, a könnyes Cócytos ${ }^{85}$, és a Tartarust körülölelő, tüzes Phlegethon ${ }^{86}$ mind a dantei pokol folyóivá válnak, főbb jellegzetességeiket meg-

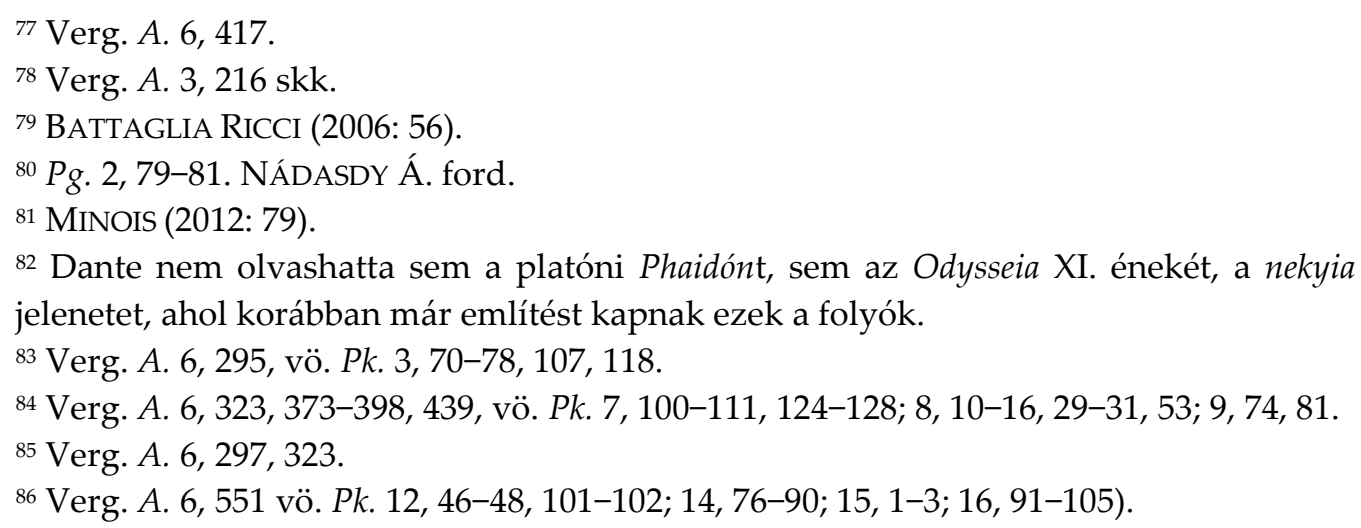


tartva; az elysiumi Léthé pedig, amely az újjászületés előtt a lelkek emlékeit törli ki, ha isznak belőle, ${ }^{87}$ a földi paradicsom egyik folyójaként „képes kitörölni / a bünök minden emlékét" 88 .

A vergiliusi túlvilág - egyik legfontosabb elözményéhez - az Odysseia 11. énekéhez képest mind topográfiájában, mind a különböző bünökhöz társított büntetések szempontjából sokkal részletesebb képet ad, így lesz a „populáris alvilágok” ${ }^{89}$ elsődleges mintája. A dantei Limbusban ${ }^{90}$ éppúgy, ahogy a Hádés küszöbénél ${ }^{11}$ a bánattól nyögnek, sírnak a korán meghalt csecsemő-lelkek. Dido és a szerelem többi halottja „kik vágyat rendeltek az ész fölé” - pokoli szélviharban „sikoltoznak, jajgatnak, nyögnek" Danténál, ${ }^{92}$ míg Vergiliusnál a Könnyek rétjén búsultak $^{93}$. Az Aeneisben a harcban elesettek és Dante viszálykeltői hasonlóképpen sebektől szenvednek a túlvilágon. A vergiliusi Deiphobus sérüléseit (kettéosztva) a Pokol 28. énekében két kortárs viszályszító, Pier da Medicina és Mosca dei Lamberti kapja büntetésként:

Déiphobus, Priamus fia jő ezután, s im a teste

Egy csupa seb s embertelenül feltépve az arca,

Már nem is arc ez, s nincs keze sem, s a fülét lemetélték,

Tőből tépték ki s borzalmas luk csak az orra. (Verg. A. 6, 494-497)

Pier da Medicina orrát és egyik fülét metszették le a dantei pokolban (Pk. 28, 64-66), Moscának pedig „mindkét kezét levágták” (uo. 103).

Miután találkoztak azokkal, akik földi sorsuk boldogtalan folytatását élik, az út kétfelé válik Sibylla és Aeneas előtt:

... a jobbra eső a hatalmas

Dís palotája felé fut, az Élysium mezejéhez;

Erre megyünk mi; a balsó evvel szemben a szörnyü

\footnotetext{
${ }^{87}$ Verg. A. 6, 714-715.

88 Pg. 28, 127-128, NÁDASDY Á. ford. A Léthé folyóról a földi paradicsomban ld.: Pg. 28, 125-133; 29, 7-8, 67-91.

${ }^{89}$ MiNOIS (2012: 78).

90 Pk. 4, 28-30.

${ }^{91}$ Verg. A. 6, 426-430.

92 Pk. 5, 39, 31, 35.

93 Verg. A. 6, 441-442.
} 
Tartarusig visz, hol vétkük levezeklik [exercet poenas] a rosszak. (Verg. A. 6, 540-543)

A Tartarus (ahová Aeneas mint jámbor nem léphet be ${ }^{94}$ ) és a dantei alsó pokol („Dis városa” $P k .8,68)$ megfeleltethető egymással: mindkettő folyóval körülvett, ${ }^{95}$ tornyos város, és mindkettőt fúriák őrzik ${ }^{96}$. A Tartarus legmélyén Iuppiter és a menny villámmal lesújtott ellenségei fetrengenek, éji homályban ${ }^{97}$, Dante poklának legmélyén hasonlóképp az Isten ellen lázadó Lucifert találjuk, távol a fénytől s melegtől (Pk. 34). Míg Homérosnál csak néhány istensértő mitikus alak - Tityus, Tantalus és Sisyphus - ítéletéről olvashatunk, ${ }^{98}$ addig a vergiliusi Tartarusról ezt mondja Sibylla:

Ámde ha száz torkom, száz nyelvem volna, s a hangom

Vasból lenne, se győzném mind szóval kifejezni,

Hány bün létezik, és hány megtorlás van ezekre. (Verg. A. 6, 625-627)

A Tartarus - a keresztény pokolhoz hasonlóan - az örökös büntetés helyszíne. ${ }^{99}$ Az Elysiumba jutás előtt pedig a lelkek ideiglenes tisztuláson mennek keresztül Anchises beavató-feltáró szavai szerint:

Hajdani bűneikért most hát kínokkal adóznak, Így vezekelnek. Van, ki szelek viharába feszítve, Van, ki viszont vízörvényben függ, vagy belemártva

Lángtengerbe, hogy az perzselje le, mossa ki bünük:

Mindegyikünk a saját lelkével szenved. A tágas

Élysiumba utána jutunk - víg földje azonban

Oly kevesek hona lesz! ... (Verg. A. 6, 739-745).

Ez a tisztuló fázis pedig a keresztény purgatórium funkciójával analóg. ${ }^{100}$

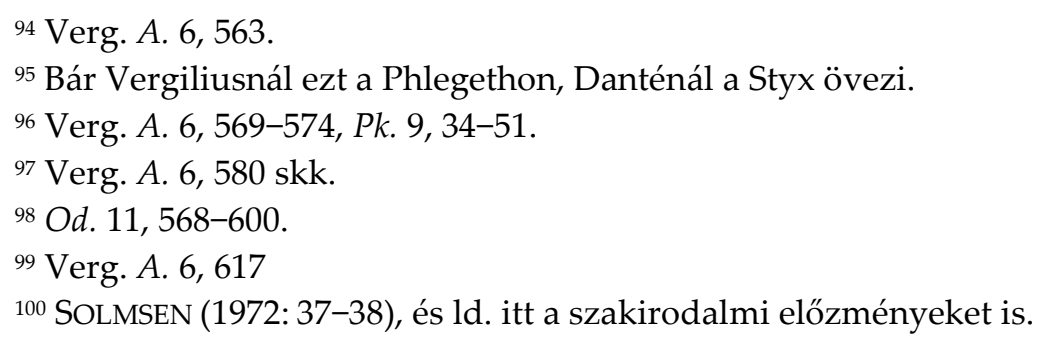


Az Aeneis olyan korszakalkotó mü, egyszerre eszkatológiai és „nemzeti” eposz, amely az epikus mintáin túl vallási és filozófiai hagyományokhoz is kapcsolódik, hasonlítható a misztériumvallások beavatási szertartásainak szövegéhez, és apokaliptikus élményt ír le. ${ }^{101}$ Aeneas mint beavatott nemcsak alászáll, hanem az Anchisesszel folytatott beszélgetés előtt "fel is kell mennie egy hegyre, mely tekinthetô az ascensio szimbólumának a szövegben":102 így válhat Aeneas túlvilági utazása sokrétű mintává Dante teljes utazásához.

Vajon Dante csupán Vergilius eposzából meríti Aeneas történetét? Az idézetek, utalások elsöprő többsége az Aeneisből származik, illetve arra mutat vissza, ám mind Ovidius „,kis Aeneis"-ét ${ }^{103}$, mind a vergiliusi szöveget magyarázó allegorikus hagyományt kimutathatóan ismerte Dante. Míg Vergilius, „legfőbb múzsánk” $(P d .15,26)$ müvét imitálja azzal, hogy a Színjátékban ismételten hangsúlyozza a próféciákon keresztül a megtett út telosát, s hogy isteni akaratból következik be, ${ }^{104}$ addig a „kis Aeneis" sürítő-újraértelmező szöveggenerációs technikája a Szinjáték klasszikus mítosz-felidézéseiben figyelhető meg.

Polydorus halálát kétszer, kétféleképp eleveníti fel Dante: először a vergiliusi, majd az ovidiusi Aeneas-történet alapján. A dantei Pokol 13. énekében, a göcsörtös-csavart fák erdejében Vergilius hívja fel az Utazó figyelmét az elkövetkező események hihetetlenségére (vagyis a szereplő Vergilius feltételezi, hogy Dante nem tartja igaznak a költő Vergilius múvének részletét), majd biztatja Dantét, hogy törjön ágat az egyik cserjéről. A sebzett ágból sötét vér csörgedezik, és a növény vérrel kevert szavakkal kér részvétet. A jelenet az Aeneis 3. énekében leírtakat idézi fel, mely szerint a trójai királyfit kincseiért Thrákiában ölték meg: a testébe fúródó lándzsák gyökeret eresztve mirtusz- és sombokorrá alakultak. A bokorból tépő Aeneas is vércseppektől és a dantei bokoréhoz igen hasonló kiáltásoktól riadt meg (Verg. Aen. 3, 22-68). A Pokol 30. énekében azonban, mikor Dante egy hasonlatban Hecuba megőrülését írja le,

\footnotetext{
${ }^{101}$ KERÉNYI (1923) és (1924). Ld. még VINCE (2005).

102 VINCE (2005), KERÉNYI (1923: 42-43).

103 Ov. Met. 13, 623-14, 580.

${ }^{104}$ Az Aeneis és az ovidiusi „kis Aeneis” összevetéséről ld. KRUPP (2009: 158-166).
} 
Polydorus történetének másik, ovidiusi változatához ${ }^{105}$ nyúl vissza, amely szerint a trójai királyfi holttestét a tengerbe dobták:
a megtört, nyomorult, rab Hecuba,
miután látta: Polüxena meghalt,
majd fiát, Polüdórost látta meg
a tengerparton elterülve holtan,
eszét vesztette, s mint egy kutya,
kínjában már csak ugatni tudott. ${ }^{106}$

\section{Aeneas és az utazó Dante}

A szereplő Dante több szempontból is megfelelteti magát Aeneasszal: számüzöttként, túlvilágjáróként, az isteni rendelés végrehajtójaként. Ahogy Aeneas Trójából menekül és új otthont keresve bolyong hosszasan, a sorsát előrevetítő jóslat igazzá válik a Firenzéből száműzött Dante számára is: „Óh, mennyi halandót, / hány italus várost koldulsz végig könyörögve!"'107. A Trója bukását hozó fortuna egyértelműen szemben áll az isteni gondviseléssel, amely utat nyitott Aeneasnak, ${ }^{108}$ hogy a lerombolt birodalom helyett máshol újat építsen. Ugyanígy a fortuna üzi el Dantét Firenzéből, és ugyanezt az isteni gondviselést vindikálja magának útjához.

A szereplő Dante végigjárja az alvilágjáró Aeneas útjának egy változatát. Az alászállást Aeneas maga kéri Sibyllától, isteni származására és precedensekre ${ }^{109}$ hivatkozva, azzal a konkrét céllal, hogy találkozhasson apjával. A trójai hős motivációja tehát a pietas, ahogy azt Anchises is kimondja az elvárt viszontlátáskor: „,vicit iter durum pietas?”110 („győzött a veszélyes uton [...] / kegyes áhitatod?").

Dante túlvilágjárásában is központi jelentőségü lesz a pietas, és nemcsak a vallásos-morális jelentésében, az isteni rendelésnek való enge-

\footnotetext{
105 Met. 13, 535 skk.

106 Pk. 30, 16-21, kiemelés tőlem.

107 Verg. A. 6, 91-92.

108 BRUGNOLI (1998: 147).

109 „hiszen járt már ott Orpheus, Théseus, Alcídés, „Pollux meg testvérével »kicserélte« haláluk" (Verg. A. 6, 119-125).

110 Verg. A. 6, 688.
} 
delmességben: útjának jelentős részét az a fiúi szeretet határozza meg, amelyet Vergilius, vezetője, „édes apja” iránt érez. Aeneas állandó jelzőjének eredete a monda, melyről Timaios, a görög történetíró számol be:

a görögök a város védelmében végsőkig kitartó néhány trójai hősnek szabad elvonulást engedtek s azt is megengedték, hogy ki-ki vigyen magával vagyonából annyit, amennyit elbír. A többiek arannyal, ezüsttel rakták tele magukat, de Aeneas öreg atyját vette vállára. A görögökben tiszteletet ébresztett a fiúi szeretet e szép megnyilatkozása s megengedték neki, hogy forduljon vissza még egyszer s vigye el házából azt, amit akar. Aeneas ekkor sem a kincsekhez nyúlt, hanem a házi isteneket ragadta ki a romok közül. Evvel érdemelte ki, hogy a trójai nép maradékát az új hazába elvezethette. ${ }^{111}$

Dante azonban nem tartja meg a vergiliusi Aeneas epitheton ornansát, hanem egy másik erényével mutatja be: Aeneas nem csak istenfélő, hanem elsősorban 'igaz' (Pk. 1, 73: giusto). A Szinjátékban a szereplő Vergilius első megszólalásakor, egyetlen tercinában határozza meg magát, főhősét és a menekülő eredeti városát:

Költố voltam, és Anchises azon igazlelkü

fiáról verseltem, aki Trójából eljött,

miután a büszke Ilion ${ }^{112}$ porig égett.

A dantei jelző forrása az Aeneis 1, 544-45. sora, mely szerint Aeneasnál igazabb, igazságosabb (iustior) senki sem volt: „Volt fejedelmünk, Aeneás: kegyesebb soha nála / S jogszeretőbb nem volt, se nagyobb, viadalban, a karddal". Dante számára az igazságosság az egyik legfontosabb erény, ${ }^{113}$ és erősen vergiliusi kötődésű. Ripheus, akinek csak néhány sort

\footnotetext{
111 TRENCSÉNYI-WALDAPFEL (1974: 281).

112 A büszke, vagyis gőgös Trója (Ilion superba) a hét főbün közül a legsúlyosabb, a superbia elrettentő példájaként szolgál a purgatóriumi gőgösök számára útba vésett képeken (Pg. 12, 61-62). A gőgös várossal szemben a dantei koncepció szerint az umile Italia ('alázatos Itália') áll, és ez a szókapcsolat szintén vergiliusi áthallás. Aeneas, mikor először megpillantja az itáliai partokat, humilis ('alacsonyan fekvő') Italia-ként nevezi meg (Verg. A. 3, 521-522), ám Dante már a legfőbb keresztény erényt tulajdonítja az eredetileg pusztán topográfiai jelzőnek (vö. RONCONI [1970: 1045]).

113 Talán, mert ő maga elszenvedője lett Firenze igazságtalanságainak (vö. Pg. 6, 124-132).
} 
szentel a latin költő, ám „iustissimus unus”-ként ${ }^{114}$ nevezi meg, Dante Paradicsomában a legigazabbak között kap helyet: az igazságos uralkodók lelkeiből kirajzolódó sas-formában a szemöldök egyik ragyogó fénye ő Isten kivételes kegyelmének példájaként ( $P d$. 20, 67-69).

Dante utazását egyéni bünössége (eltévelyedése a bünök allegorikus sötét erdejében) teszi szükségessé, azonban lehetővé csak az isteni kegyelem miatt válik. A kegyelem szükséges előfeltétele pedig az érdem, amely Dante esetében a költői érdem. Mindhárom elem (bűnösség, kegyelem, érdem) toposz a középkori túlvilágjárásokban: az isteni kegyelem elengedhetetlen a holtak birodalmából élve kijutáshoz és a paradicsom látásához. Az utazó bűnössége vagy érdeme közül viszont általában csak az egyik hangsúlyos: így Szent Pál és Tundalus ${ }^{115}$ esetében a bün; mások, mint Szent Brendan ${ }^{116}$ és Mohamed ${ }^{117}$ kiválasztottként, hitükért, vallási érdemeikért nyerik el a betekintést a halál utáni birodalmakba. Habár Vergilius Aeneasa a katabasis kérésekor nem hivatkozik semmilyen érdemére, csupán isteni származására és céljára, Dante (e másik hagyomány hatása alatt) fontosnak tartja Aeneas erényeit és érdemeit - nemességét, erkölcsösségét, kiválóságát - hangsúlyozni (vö. Egyed. II iii 7-17).

$\mathrm{Az}$ Aeneas isteni származását illető részt pedig Dante allegorikusan interpretálja, hogy így magára is vonatkoztathassa:

[a megfelelő óvatosság és a helyes választani tudás] megvannak [...] mindazokban, akiket a Költő az Aeneis VI. énekében olyanoknak mond, akiket az Isten kedvel, s lángoló virtus az égbe emelt, s istenek fiainak hívja óket, ámbár mindezt csak képletesen mondja. ${ }^{118}$

A felidézett szöveghelyen Sibylla szavai Aeneast figyelmeztetik a katabasis előtt:

\footnotetext{
114 Verg. A. 2, 426.

115 Míg Tundalus teste tetszhalál állapotában tölt három napot, addig lelke, éppúgy, mint Dantéé, a túlvilági utazás során büneitől megtisztul. Magyarul: DRASKÓCZY E. Tundalus látomása, kézirat.

${ }^{116}$ Magyarul: MAJOROSSY J. ford. Szent Brendan apát tengeri utazása.

117 Magyarul: SIMON R. ford. Liber Scale. Saját fordításomban a jegyzetek a dantei Színjátékkal való párhuzamokat emelik ki: Mohamed lépcsőjének könyve, kézirat.

${ }^{118}$ DVE II iv 10-11, Mezey László ford., KARDOs 1965: 382. (Kiemelés tőlem - D. E.)
} 
Trójai Anchísés fia! könnyü leszállni a mélybe -

Nyitva a gyászteli Díshez, nap mint éj, a bejárat -,

Ámde kijönni megint az Avernusból, fel a fényre,

Ez fáradságos feladat! Csak a lángszivü bírja,

Kit kedvel Jupiter, vagy az égig emel fel erénye,

Vagy pedig isteni sarj maga is. (Verg. A. 6, 126-131)

Az isteni sarj alatt Bernardus Silvestris Calliope fiait érti, vagyis az ékes szavúakat, és kiemeli közülük Orpheust, a par excellence költőt. ${ }^{119}$ Dante ennek az értelmezésnek a felidézésével von párhuzamot egyrészt Aeneas és tulajdon alvilágjárása között, másrészt Orpheus és önmaga között: Orpheus alvilágjáróként Aeneas mintája (Verg. A. 6. 119), Danténak pedig költő alvilágjáróként kétszeresen is fontos előkép. A thrák dalos az elysiumi mezőn „hosszú köpönyegben, / pengeti hét húrú lantját, melyhez hol az újja, / hol meg a szín-elefántcsont vessző vége a szerszám”"120, Danténál pedig ezt a vergiliusi vidéket idéző Limbusban látható. Bernardus Silvestris allegorikus értelmezését elfogadva Dante tehát önmagát mint „Calliope fiát", vagyis mint költőt hatalmazza fel a túlvilági utazásra.

Aeneas modellszerepe nem ér véget az édenkertben, ahol Vergilius elbúcsúzik Dantétól. Az Utazó - még mielőtt a paradicsom felé elindulna - megtapasztalja az ember fölöttivé válást ${ }^{121}$, és a mennyei élmények hatására egyre inkább fölébe nő emberi képességeinek ${ }^{122}$, ám az istenlátáshoz külön égi engedélyre lesz szüksége. Dante harmadik vezetője, Szent Bernát Máriához könyörög, ${ }^{123}$ hogy az Utazó halandó korlátai nélkül érzékelhesse Istent:

imáiddal üzz el minden ködöt

halandó szeméről, hogy neki is

megmutatkozzon a Legfőbb Gyönyör! ${ }^{124}$

\footnotetext{
119 Bernardus Silvestris, 57. Idézi: BELLOMO (2013: L).

${ }^{120}$ Verg. A. 6, 645-647.

${ }^{121}$ Pd. 1, 70: trasumanar.

122 Pd. 30, 56-57: „ch'io compresi / me sormontar di sopr' a mia virtute".

${ }^{123} \mathrm{Pd} .33,1-39$.

124 Pd. 33, 31-33. NÁDASDY Ádám fordítását idézem.
} 
Szent Bernát imája több részletében is idézi Venus fohászát, aki Aeneas apotheosisáért könyörög Jupiterhez ${ }^{125}$. Mindkét könyörgésben jelen van a megtett út érve: hogy Aeneas „átkelt már egyszer a Styxen”, és Dante megjárta az alvilágot ( $P d$. 33, 22-27):

Itt ez az ember, aki a világ

legmélyebb gödrétôl kezdve fokonként

végignézte a lelkek életét:

hozzád fohászkodik, légy most kegyes,

töltsd el erővel, hogy tekintetét

a végső üdvre rá tudja emelni.

Venus és Szent Bernát imája egyaránt meghallgatásra talál: Aeneasról eltünik minden, ami halandó, és csak a nemesebbik rész marad meg:

Ennek rendeli: Aeneasról, mind, mi halandó, mossa le és csöndben görgesse a tenger ölébe;

rögtön a szarv-viselő elvégzi, amit Venus óhajt:

és tisztítja le Aeneasról mind, mi halandó,

hinti vizével; csak nemesebbik része maradt meg.

Az utazó Dante pedig elnyeri az emberi szavakkal leírhatatlan, mennyei látás élményét $(P d$. 33, 46-57. s.):

És én, ki vágyaim teljesülését

már közel éreztem, szükségszerűen

egyre nagyobb kívánsággal lobogtam. ...

tekintetem egészen kitisztult

s kezdett a Magas Fénybe behatolni,

amelynek sugara merő Igazság.

Látásom ettől fogva több s nagyobb volt,

mint amit elbír az emberi nyelv,

$\mathrm{s}$ az emlékezet innen visszahőköl.

125 „Mindegyik égilakót megnyerte Venus, megölelte / apja nyakát, s így szólt: “Sose voltál mostoha hozzám, / édesapám, hanem azt kérem: most legkegyesebb légy, / s Aeneasomnak, ki a vérünkből nagyapává/ tett téged, ha kis istenséget is, adj neki mégis / ezt legalább! Elegendő volt, hogy a zord birodalmat / egyszer látta fiam, s átkelt már egyszer a Styxen." Ov. Met. 14, 585-591. DEVECSERI Gábor fordítását idézem. 


\section{Konklúzió}

Az utazó Dante kezdeti, félelemből és kishitüségből fakadó tagadását (,nem vagyok Aeneas”) a Vergilius vezette pokol- és purgatórium-járás számos Aeneis-utalása és újraírása egy ki nem mondott állítássá változtatja (új Aeneas vagyok). A megújulás lényege a keresztény tartalom, amely az allegorikus kommentárok értelmezését követi, de Dante a mü minden szeletében több hagyományra építkezve száll versenybe elődeivel. Így túlvilágjáróként felhasználja Aeneas tapasztalatait (reakcióit, alvilág-térképét, találkozásait), legfőbb erényeit, céltudatosságát, sőt, modelljét, Orpheust is, ám a Színjáték útja továbbvezet a Vergilius által leírtaknál, hogy a bibliai és apokaliptikus hagyományból, majd a középkori látomásirodalomból is táplálkozva alkossa meg az Utazó identitását.

\section{Rövidítésjegyzék (Dante müvei magyarul)}

Egyed. $=$ Az egyeduralom, ford. Sallay Géza, in: KARDOS 1965: 401-476.

XIII. Lev.= Tizenharmadik levél, ford. Mezey László, in: KARDOS 1965: 505-519.

Pd. $=$ Paradicsom

Pg. =Purgatórium

$P k .=$ Pokol

Szinjáték = Alighieri, Dante, Isteni Szinjáték, ford. NÁDASDY Á. Budapest, 2016.

Vend. = Vendégség, ford. Szabó Mihály, in: KARDOs 1965: 155-346.

\section{Források}

Dante Alighieri összes müvei, KARDOS T. szerk., Budapest, 1965.

Benevenuti de Rambaldis de Imola Comentum super Dantis Aldigherij Comoediam, nunc primum integre in lucem editum sumptibus Guilielmi Warren VERNON, curante Jacobo Philippo Lacaita. Florentiae, 1887.

Commentum quod dicitur Bernardi Silvestris super sex libros Eneidos Virgilii, J. JONES - E. JONES (eds.), Lincoln, Neb., 1977.

Giovanni Boccaccio, Esposizioni sopra la Comedia di Dante, a cura di Giorgio Padoan, vol. VI di Tutte le opere di Giovanni Boccaccio, a cura di Vittore BRANCA, Milano, 1965.

Liber Scale, in SIMON. R., Etüdök a halálról. Túlvilági utazás a mazdaizmusban és az iszlámban, Budapest, 2013, 259-367.

Mohamed lépcsőjének könyve, DRASKÓczY E. ford., kézirat.

P. Ovidius Naso, Átváltozások, DeVECsERI G. ford., Budapest, 1964. 
P. Ovidius Naso, Keservek, ERDŐDY J. et al. ford., Budapest, 2002.

Péter-apokalipszis, PESTHY M. ford., Budapest, 2009.

Szent Brendan apát tengeri utazása. Navigatio Sancti Brendani Abbatis, MAJOROSSY J. ford. Documenta Historica, 53, Szeged, 2001.

Szent Pál apostol látomása, in: DÖRÖMBÖZI J. - ADAMIK T. (szerk.) Apokalipszisek, Budapest, 1997, 73-100.

Tundalus látomása, DRASKÓcZY E. ford., kézirat.

Vergilius összes müvei, LAKATOS I. ford., Budapest, 1967, 2009.

P. Vergili Maronis: Opera, R. A. B. MYNORS (ed.), Oxford, 1969.

\section{Felhasznált irodalom}

BALL 1991

R. BALL, Theological Semantics: Virgil's Pietas and Dante's Pietà, in: R. Jacoff - J. T. Schnapp (eds.) The Poetry of Allusion: Virgil and Ovid in Dante's Commedia, Stanford, 1991, 19-36.

BAROLINI 1993 T. BAROLINI, Il miglior fabbro: Dante e $i$ poeti della "Commedia", Torino, 1993.

BAROLINI 2015 T. BAROLINI, Miért irta meg Dante a Színjátékot? Dante és a látomásirodalmi hagyomány, ford. Molnár A., Filológiai Közlöny, 4, 2015, 462-468.

BATTAGLIA Ricci 2006 L. BATTAGLIA RICCI, "Vidi e conobbi l'ombra di colui". Identificare le ombre, in M . M . Donato - L . Battaglia Ricci - M . Picone - G . Z. Zanichelli (eds.) Dante e le arti visive, Milano, 2006, 49-80.

BELlOMO 2013 S. Bellomo, L'Inferno di Dante, Torino, 2013.

BORZSÁK 1968 BORZSÁK I., Az Aeneis alvilági seregszemléjének utókorához, Irodalomtörténeti Közlemények 72/4 (1968), 432-436.

BROWNLEe 1993 K. BROWNLEe, Dante and the classical poets, in: R. Jacoff (ed.), The Cambridge Companion to Dante, Cambridge, 1993, 100-19.

Brugnoli 1998 G. BRugnOLI, Studi danteschi. Vol. 2: I tempi cristiani di Dante e altri studi, Pisa, 1998.

CASAli 1995 S. CASALI, Altre voci nell'"Eneide" di Ovidio, in: Materiali e discussioni per l'analisi dei testi classici, 35 (1995), 59-76.

COMPARETTI 1872 D. COMPARETTI, Virgilio nel medio evo, Livorno, 1872.

COnsol-Ronconi 1976 D. CONSOli - A. RonCOni, Virgilio Marone, Publio, in: U. Bosco (ed.), Enciclopedia Dantesca, vol. 5, Roma, 1030-1043.

ERTL 2018 ERTL P. (ford.), Francesco Petrarca: Liber sine nomine. Cím nélküli könyv, Szeged, 2018.

FORTE

A. FORTE, «A l'altra riva». I traghettatori infernali da Virgilio alla ricezione scritta e figurata della Commedia, kézirat.

HAWKINS 1999 P. S. HAWKINS, Descendit ad inferos, in: Dante's Testaments: Essays in Scriptural Imagination, Stanford, 1999, 99-124.

Hoffmann-Mátyus Hoffmann B. - Mátyus N., A Pokol II. éneke, in: szerk. Kelemen J., A dantei Pokol: kommentárok. megj. alatt. 
HOFFMANN-MÁTYUS 2013

Hoffmann B. - MÁtYus N., A Pokol II. éneke, Dante Füzetek X. (2013), 1-62.

Hollander 1983 R. HOllander, Il Virgilio dantesco: Tragedia nella "Commedia", Firenze, 1983.

Hollander 1993 R. Hollander, Le opere di Virgilio nella "Commedia" di Dante in: A. A. Iannucci (ed.), Dante e la "bella scola" della poesia. Autorità e sfida poetica, Ravenna, 1993, 247-343.

ItAlia 2008 S. ItALIA, Dante e Servio. "Sotto 'l velame de li versi strani», in: S. Cristaldi - C. Tramontana, L'opera di Dante fra Antichità, Medioevo ed epoca moderna, Catania, 2008, 329-417.

ITALIA 2012 S. ITALIA, Dante e l'esegesi virgiliana. Tra Servio, Fulgenzio e Bernardo Silvestre, Roma, 2012.

JACOFF-SCHNAPP 1991 R. JACOFF - J. T. SCHNAPP, Introduzione. Virgil in Dante, in: The Poetry of Allusion: Virgil and Ovid in Dante's Commedia, Stanford, 1991, 2-9.

KERÉNYI 1923

KERÉNYI K., Ascensio Aeneae. A görög apokalyptika történetéhez, Egyetemes Philológiai Közlöny, 47 (1923), 22-43.

KERÉNYI1924 KeRÉNYI K., Ascensio Aeneae II. Újabb kutatások az Aeneis VI. énekének magyarázatához, Egyetemes Philológiai Közlöny, 48 (1924), 21-33.

KRUPP 2009

J. KRUPP, Distanz und Bedeutung, Heidelberg, 2009.

LEDDA 2008

G. LEDDA, G., Dante e la tradizione delle visioni medievali, Letture Classensi, 37 (2008), 119-142.

LEDDA 2011

G. LeDDA, Modelli biblici nella "Commedia": Dante e san Paolo, in: Id. (ed.), La Bibbia di Dante. Esperienza mistica, profezia e teologia biblica in Dante, Ravenna, 2011, 179-216.

MÁTYUS-NAGY

MINOIS 2012

MÁtYus N. - NAgY J., A Pokol I. éneke, in: Kelemen J. (szerk.), A dantei Pokol: kommentárok (kézirat).

PADOAN 1970

MinOIS, G., A pokol története, Budapest, 2012.

G. PADOAN, "Enea." in: U. Bosco (ed.), Enciclopedia Dantesca, vol. 2, Roma, 1970, 677-679.

PADOAN 1977 G. PADOAN, Tradizione e fortuna del commento all'Eneide' di Bernardo Silvestre, in: Il pio Enea, l'empio Ulisse, Ravenna, 1977, 207-222.

Padoan 1993 G. PAdOAN, Il lungo cammino del "Poema sacro": studi danteschi, Firenze, 1993.

PAdOAN 2001 G. PADOAN, $A$ "szóban mester" Odüsszeusz és a tudás útjai. Egy hagyomány állomásai (Vergiliustól Dantéig), in: Dante a XX. században, Helikon 47/2-3 (2001), 321-350.

PÁL 2009

PÁL J., Dante: szó, szimbólum, realizmus a középkorban, Budapest, 2009.

PiCONe 2017 PICONe M., Gli ipotesti classici (Virgilio e Ovidio) in: Id., Scritti danteschi (ed. A. Lanza), Ravenna, 2017 (a tanulmány első megjelenése: 2008). 
Petrocchi 1966-1967 G. Petrocchi (ed.), Dante Alighieri: La Commedia secondo l'Antica Vulgata, Milano, 1966-1967.

Petrocchi 1988 G. Petrocchi: San Paolo in Dante, in: G. Barblan (ed.), Dante e la Bibbia, Firenze, 1988, 235-248.

Putnam 1991 M. C. J. Putnam, Virgil's Inferno, in: R. Jacoff - J. T. Schnapp (eds.), The Poetry of Allusion: Virgil and Ovid in Dante's Commedia, Stanford, 1991, 94-112.

Rigo $1994 \quad$ P. Rigo, Memoria classica e memoria biblica in Dante, Firenze 1994.

RONCONI 1976 A. RONCONI, Echi virgiliani nell'opera dantesca, in: U. Bosco (ed.), Enciclopedia Dantesca, vol. 5, Roma, 1976, 1044-49.

SAllay 2011 SAllay G., Dante és Vergilius az Inferno I-II. énekében. In: Szegedi E. - Falvay D. (szerk.): „Ritrar parlando il bel”. Tanulmányok Király Erzsébet tiszteletére, Budapest, 2011, 17-31.

SIIKALA-DIEZ DE VELASCO 2005

L. SiIKAla - F. Diez DE Velasco, Descent into the Underworld, L. Jones - M. Eliade - C. J. Adams (eds.) Encyclopedia of Religion, 2005.

SOlmSEn 1972 SolmSEN, F., The World of the Dead in Book 6 of the Aeneid, Classical Philology 67/1 (1972), 31-41.

TóтH Tóтн T., A Pokol IV. éneke, in: Kelemen J. (szerk.), A dantei Pokol: kommentárok (kézirat).

TRENCSÉNYI-WALDAPFEL 1974

TRENCSÉNYI-WALDAPFEL, Mitológia, Budapest, 1974.

VINCE 2005 VINCE M., „Ha az álom kapuja kitárul”, in: Ferenczi A. (szerk.), A rejtélyes Aeneis, Budapest, 2005, 89-116.

VÍGH 2017 VÍGH É., "Ordít az oroszlán: ki ne rettegne?”, Filológiai Közlöny 63/1 (2017), 87-100.

ZIOLKOWSKI-PUTNAM 2008

J. M. Ziolkowski - M. C. J. Putnam (eds.), The Virgilian tradition: the first fifteen hundred years, New Haven, 2008. 